doi: $10.18575 /$ msrs.sm.e.17.22 UDC 616.366-003.7-072.1-71-089 COBISS.RS-ID 6837528

\title{
Laparoscopic Cholecystectomy in a Patient with Inversion of the Abdominal Cavity
}

\begin{abstract}
Situs viscerum inversus totalis is a rare condition in which organs are transposed from the normal side to the opposite side in the abdominal and chest cavity. It occurs in a ratio from 1:5000 to 1:20000. In this case report, a case of a 50-yearold man who was diagnosed with the symptomatic presence of gallstones with the usage of ultrasound. The patient underwent the laparoscopic cholecystectomy, the surgical procedure lasted for 90 minutes, it was successfully completed and the patient was discharged on the first postoperative day.
\end{abstract}

(Scr Med 2017:48:145-147)
Igor Stakić ${ }^{1}$ Vladimir Keković ${ }^{1}$, Milan Simatović, Dragan Kostić ${ }^{2}$

${ }^{1}$ Clinic for General and Abdominal Surgery, University Clinical Center of the Republic of Srpska, Banja Luka

${ }^{2}$ Special Surgical Hospital Dr Kostić Banja Luka

\section{Contact address:}

Igor Stakić

Street address: Zdrave Korde 1 78 ooo Banja Luka

Republic of Srpska Bosnia i Herzegovina e-mail: istakic@gmail.com phone number: +387-66-876-666

Submitted: August 28 ${ }^{\text {th }}, 2017$ Accepted: September 13 ${ }^{\text {th }}, 2017$

\section{Introduction}

Situs viscerum inversus totalis is characterized by the transposition of main organs of the chest and all the internal organs of the abdominal cavity to the side opposite to the normal position in the body. The liver and gallbladder are located on the left side, while the stomach and spleen on the right. Normal organogenesis requires a 270 degree rotation in the direction opposite to the clockwise direction, which gives a normal anatomy. In situs inversus totalis, a 270 degree rotation is in the clockwise direction. ${ }^{1}$ The incidence of situs viscerum inversus ranges from 1 to 5000 to 1 at $20000 .^{2,3}$ Thus, the stomach and spleen are located on the right side (Picture 1.) and liver and gallbladder on the left (Picture 2.).

A ratio between the occurrence in sexes is 1:1, and there is no racial inclination. This condition can be associated with cardiac anomalies as well as with Kartagener's syndrome (bronchiectasis, sinusitis, situs inversus).2,4 There are no data suggesting the increased incidence of gallstones in patients with situs inversus totalis. ${ }^{5}$ The first case of situs viscerum inversus was described by Fabricius in $1600 .{ }^{1}$ This phenomenon has been known to be present in animals since the time of Aristotle. ${ }^{2}$ The first known laparoscopic cholecystectomy in patients with situs inversus was published by Campos and Sipes in $1991 .{ }^{1}$ Due to the nature of the reverse organ arrangement and possible joint anomalies, the surgery is quite demanding, even for an experienced surgeon. ${ }^{3,6}$

Picture 1. Part of the Stomach Seen on the Right

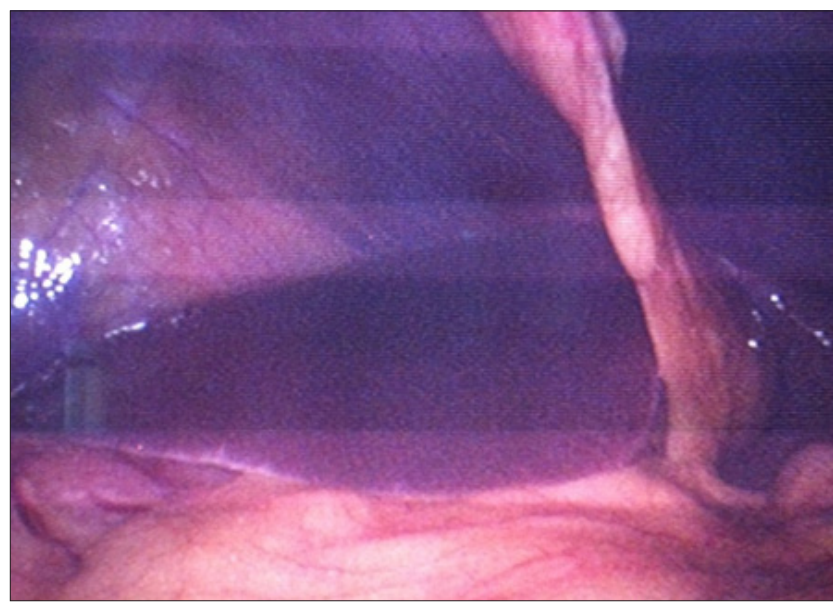


Picture 2. The Gallbladder on the Left



\section{Case Report}

A 50-year-old man was admitted to the Clinic for General and Abdominal Surgery, UCC of the Republic of Srpska, due to elective gallbladder removal operation. We anamnestically obtained the information that the patient had reported to the doctor due to the pain behind the left arch three months earlier. The problems occurred after a meal. Afterwards, he was referred for an ultrasound examination of the abdomen where gallstones were detected (a calculus of $12 \mathrm{~mm}$ in diameter), and situs viscerum inversus totalis was confirmed. During the military service, the patient was diagnosed with situs viscerum inversus which was confirmed by a PA chest radiograph. The patient had no other difficulties nor was he treated for a chronic illness. The first time he addressed to the doctor was because of the aforementioned problem.

The patient was placed in a lying position with a surgeon who was located on the patient's right, and the assistant on the left. On the left side was the monitor that was located next to the head of the patient. A $10 \mathrm{~mm}$ laparoscope was introduced through the umbilical incision. The next 10 $\mathrm{mm}$ trocar was introduced in the sub-axial area in the middle. Two $5 \mathrm{~mm}$ triangles were introduced in the left middle clavicular and left front axillary line. The grip manipulated by the assistant was introduced through a trocar in the front axillary line to hold the gallbladder fundus and pull the gallbladder laterally and cranially. The second grip, which was manipulated by the surgeon with his right hand, was introduced through a trocar in the middle axillary line in order to hold the gallbladder neck. Through the sub-xiphoid trocar, a dispenser manipulated by the surgeon with his left hand was introduced. The process of preparing the elements of Calot's triangle was done with a left hand, which was a significant problem for a surgeon whose dominant hand was right. It is common during the operation that the surgeon takes a disorder with his right hand, and the assistant keeps the gallbladder neck with a grip on the central axillary line. The arthritis of the cystic and the ductus cysticus were doubly individually clipped with titanium clips, while the gallbladder was removed from its place by an anterograde route. The operation lasted for 90 minutes and was successfully completed (Figure 3).

Figure 3. Arrangement of Incisions on the Abdominal Wall



On the first postoperative day, the active drainage set during the surgery was taken out and the patient was discharged for home treatment.

\section{Discussion}

Situs inversus totalis is a very rare condition, and successful laparoscopic cholecystectomy in these patients is even rarer. In July 2006, Bediou published the $13^{\text {th }}$ case in the world. ${ }^{7}$ None of these cases was from Bosnia and Herzegovina. In our case, both surgeons had a dominant right hand. The modifications in the technique were also described in a way that the assistant holds the gallbladder neck with the grip, while the surgeon prepares elements of the Calot's triangle with the right hand, which happened in some segments during our operation. Arya and associates published a paper in which he described how he performed a laparoscopic cholecystectomy with situs viscerum inverusus with two assistants, and the arrangement of ports he used was the same as in our case. ${ }^{8}$ The difference with regard to his approach was that he had an assistant more in relation to us, who stood by the operator and held the gallbladder neck with the grip. Furthermore, there is a description in literature regarding the modification where the patient was in a position with his legs in abduction (Lloyd-Davis) and where the operator was between the patient's legs, which 
was not our method of choice. ${ }^{9}$

\section{Conclusion}

A surgeon with a dominant right hand should prepare the elements of Calot's triangle with his right hand without using his left hand.

It is much easier for a surgeon whose dominant side is left to perform laparoscopic cholecystectomy in patients with situs viscerum inversus totalis.

\section{References}

1. Song JY, Rana N, Rottman CA. Laparoscopic appendicectomy in a female patient with situs inversus: Case report and literature review. JSLS. 2004;8:175-177 PMid:15119665 PMCid:PMC3015541

2. McKay D, Blake G. Laparoscopic cholecystectomy in situs inversus totalis: A case report. BMC Surg. 2005;5:5.

https://doi.org/10.1186/1471-2482-5-5

PMid:15774004 PMCid:PMC555757

3. Kumar S, Fusai G. Laparoscopic cholecystectomy in situs inversus totalis with left-sided gall bladder. Ann R Coll Surg Engl. 2007;89:16-18. https://doi.org/10.1308/147870807X160461 PMid:17346394 PMCid:PMC1964589

4. Malatani TS, Laparoscopic cholecystectomy in situs inversus totalis:a case report and review of of the literature.
Ann Saudi Med 1996;16(4):458-459.

https://doi.org/10.5144/0256-4947.1996.458

5. Eisenberg D. Cholecystectomy in situs inversus totalis: A laparoscopic approach. Int Med Case Reports J. 2009;2:27-29. https://doi.org/10.2147/IMCRJ.S7702

6. Pitiakoudis M, Tsaroucha AK, Katotomichelakis M, Polychronidis A, Simopoulos C. Laparoscopic cholecystectomy in a patient with situs inversus using ultrasonically activated coagulating scissors.Report of a case and review of the literature. Acta Chir Belg. 2005;105:114-117. PMid:15790219

7. Kamitani S, Tsutamoto $\mathrm{Y}$, Hanasawa $\mathrm{K}$, Tani $\mathrm{T}$. Laparoscopic cholecystectomy in situs inversus totalis with "inferior" cystic artery: A case report. World J Gastroenterol. 2005;11:5232-5234.

PMid:16127760 PMCid:PMC4320403

8. Arya SV, Das A, Singh S, Kalwaniya DS, Sharma A, Thukra BB. Technical difficulties and its remedies in laparoscopic cholecystectomy in situs inversus totalis: a rare case report. Int J Surg Case Rep. 2013;4:727-730.

https://doi.org/10.1016/j.ijscr.2013.05.012

PMid:23816750 PMCid:PMC3710905

9. Yaghan RJ, Gharaibeh KI, Hammori S. Feasibility of laparoscopic cholecystectomy in situs inversus. J Laparoendosc Adv Surg Tech A. 2001;11:233-237. https://doi.org/10.1089/109264201750539763 PMid:11569514

\section{Laparoskopska holecistektomija kod pacijenta sa inverzijom organa trbušne duplje}

\section{SAŽETAK}

Sit Situs viscerum inversus totalis je rijetko stanje kod koga su organi transpozicionirani sa normalne strane na suprotnu stranu u trbušnoj i grudnoj duplji. Javlja se od 1:5000 do 1:20000. U prikazu slučaja, radi se o muškarcu starom 50 godina, kod koga je ultrazvučno dijagnostikovano simptomatsko prisustvo kamenaca u žučnoj kesi. Podvrgnut je laproskopskoj holecistektomiji, operativni zahvat je trajao 90 minuta, te je uspješno završen, a pacijent je otpušten kući prvog postoperativnog dana. 